\title{
Nigella Sativa and Oriental Spices with Protective Role in Iron Intoxication: in vivo Experiments on Rabbits
}

\author{
Mirela AHMADI ${ }^{1}$, Dorel DRONCA ${ }^{2 *}$, Gianina DODI ${ }^{3}$, Cornelia MILOVANOV ${ }^{1}$, Dinu GAVOJDIAN ${ }^{4}$, Cristian \\ DUMITRU $^{3}$, Mihaela SCURTU ${ }^{3}$
}

${ }^{1}$ Department of Biochemistry and Molecular Biology. Banat University of Agricultural Sciences and Veterinary Medicine "King Michael I of Romania" from Timisoara (USAMVB), Calea Aradului 119, Timişoara - 300645, România.

${ }^{2}$ Department of Animal Genetic Improvement, USAMVB, Calea Aradului 119, Timişoara - 300645, România.

${ }^{3}$ S.C. Scient CromatecPlus - Research Development Innovation Centre for Instrumental Analysis

S.R.L., Str. Petre Ispirescu, nr 1, Sat Tancabesti, Com. Snagov, Ilfov - 077167, România.

${ }^{4}$ Romanian Academy of Agricultural and Forestry Sciences, Sheep and Goats Research and Development Regional Station, Str. Reşiței, Caransebeş - 325400, Caraş-Severin County, România.

* corresponding author: ddronca@animalsci-tm.ro

Bulletin UASVM Animal Science and Biotechnologies 73(2)/ 2016

Print ISSN 1843-5262; Electronic ISSN 1843-536X

DOI:10.15835/buasvmcn-asb: 12232

\begin{abstract}
Homeostasis of hematological parameters is essential for assuring the general health status of any living organism. Iron is one of the essential minerals, involved in many vital processes - mainly in blood cells. Also iron can become toxic for organism in very high concentration. Hemoglobin and red blood cells are directly related with the iron ion, due to the high quantity (70\%) of total iron in the organism being part of blood (hemoglobin) and muscle (myoglobin) cells. Administration of high doses of iron can negatively affect the general health status, because iron alters the enzymatic system of vital organs. The aim of our experimental study was to verify and demonstrate that fresh, organic vegetables and legumes protect the rabbit's organism, after intraperitoneal administration of iron $15 \mathrm{~g} \mathrm{Fe}^{2+} / \mathrm{Kg}$ body weight as ferrous-gluconate hydro solution, help the hematological homeostasis. The research experiment was conducted during 43 days in summer time, on German Lop Eared breed young rabbits, one control and one experimental group (5 animals each group). During experiment rabbits had a special diet consisted of Nigella sativa, Allium ampeloprasum, Allium tuberosum, Coriandrum sativum, Eruca sativa, Cucumis sativus, Raphanus sativus, Trigonella foenum-graecum, Trifolium, Petroselinum crispum, Dacus carrota subsp. sativus and Cucumis sativus). At the end of the experiment we collected blood samples for hematological test and we evaluated the number of erythrocytes, leukocytes, platelets; hemoglobin, hematocrit, mean corpuscular volume, mean corpuscular hemoglobin, mean corpuscular hemoglobin concentration, and red cell distribution width. Results were evaluated analytically and a significant increase was recorded only for hemoglobin in experimental rabbits compared to the control group.
\end{abstract}

Keywords: iron intoxication, Nigella sativa, oriental spices, rabbits

\section{INTRODUCTION}

Iron is an essential mineral for the human and animal organism, but the chemical form and the quantity of the intake makes the difference between the benefic and harmful effect. Also, the association of iron intake with other substances can affect the bioavailability of this nutrient. The chemistry of iron related to biological systems involves the oxidation-reduction process of $\mathrm{Fe}^{2+}$ to $\mathrm{Fe}^{3+}$ or reverse, being part of various chemical 
substances with a very important role in the organism. Many metalloproteins and enzymes have the iron ion in the structure. Because it can play with the electronic state, iron is involved in lots of oxidation and reducing processes. In animal and human organism there are two important types of iron: heme and nonheme iron. One of the main compounds with iron is hemoglobin a blood porphyrinic compound (heme iron) that contains in its structure ferrous ion, involved in oxygen transport to cells. Keeping the balance between iron intake and excretion is possible only by adjusting absorption (Hurrell and Egli, 2010).

Iron is an essential element for the human and animal organism, but in high concentrations becomes toxic for cells. Up to $90 \%$ of the iron used daily by the body comes from endogenous processes, mainly from the break down of red blood cells (hematia), but exogenous sources are also very important and have to be taken into consideration. Dietary factors are modulating iron bioavailability, acting as iron absorption inhibitors (phytate, polyphenols, calcium, and proteins) or as iron absorption enhancers (ascorbic acid, or association of ascorbic acid with fumaric acid, or lactic acid, or succinic acid) - Teucher et al., 2004.

One protein involved in iron homeostasis is hepcidin - a peptide produced by hepatocytes and adipocytes. Thus, the balance of iron in the organism is kept by liver activity, and the deficiency is related also to obesity. General health status of the organism is directly involved in iron homeostasis (for example infection or inflammation processes leads to iron deficiency) - Hurrell and Egli, 2010.

Some plants accumulate important iron quantities from soil. Thus, Hajiboland et al. (2013) demonstrated that Camellia sinensis (tea leaves and roots) accumulates iron and aluminum from soil, but the aluminum limits iron uptake from edible parts of the tea plant. This is explained by translocation and by decreasing iron uptake because aluminum induces growth stimulation. The process is used as protection against high concentrations of potential toxic iron in young tea leaves.

Dietary sources of iron are very important, but the bioavailability is related to the quantity and quality of the food or feed. Starting from this hypothesis we aimed to test the intake of iron in excess quantities, associated with a dietary plan involving different oriental plants with protective role on metal toxicity. The chemical form of iron was chosen based on the bioavailability of the iron, and for this reason we used ferrous gluconate for iron overdose, in two different concentrations, on German Lop Eared Rabbits. In the rabbit's experimental diet we used fresh and organic plants from our experimental garden.

One of the protective plants used in iron intoxication experiment was Nigella sativa used as seeds. Nigella sativa is a medicinal plant with quinoid compounds, with high medical and pharmaceutical importance (Ahmad, 2013; Beheshti et al., 2016; Sahebkar et al., 2016). Nigella sativa in various forms was used in traditional medicine for high blood pressure; for protective effect on hepatic, kidney and lung metabolic activity enhancement; for dermatitis, for digestive diseases; and also for anti-bacterial, anti-inflammatory and anti-pyretic effect. But lately, thymoquinone from this plant, modulates the humoral and cellular adaptive immune and inflammatory response (Majdalawieh and Fayyad, 2015), and is used for its anticancer activity (Kundu et al., 2014; Periasamy et al., 2016).

\section{MATERIALS AND METHODS}

Our research experiment was conducted on young German Lop Eared rabbits (five weeks old rabbits), after weaning, each weighing between 580-800g ( $X=703 g$, SD 89.19), (Dronca, 2007). The experiment included two working groups: one control (C) and one experimental group (E), with five animals each $(2$ males and 3 females for each group). The research experiment was performed during summer (43 days), during which we formed the groups and let the animals adjust, and then we administered iron as ferrous-gluconate hydrated $\left(\mathrm{C}_{12} \mathrm{H}_{26} \mathrm{FeO}_{16}\right.$ - Fluka Producer) in concentrations that provided $15 \mathrm{~g}$ $\mathrm{Fe}^{2+} / \mathrm{kg}$ body weight for experimental group (E). We repeat iron administration after seven days. The administration was done as intraperitoneal (ip) injections, and the chemical form of iron was gluconate because is hydro soluble, and ferrousgluconate bioavailability is good for animal and human organism.

In our dietary protective plan against iron intoxication we used fresh, organic plants for experimental rabbits, such as black seed of Nigella sativa, clover (leaves) - Trifolium, garden parsley 
(leaves) - Petroselinum crispum, leek (leaves) Allium ampeloprasum, chives (leaves) - Allium tuberosum, coriander (leaves) - Coriandrum sativum, rucola (leaves) - Eruca sativa, cucumber (fruit) - Cucumis sativus, radish (roots and leaves) - Raphanus sativus, fenugreek (leaves) - Trigonella foenum-graecum, carrots - Dacus carrota subsp. sativus and cucumber - Cucumis sativus.

During our experimental research we kept rabbits according with good practice guidelines and we respected animal protection lows, assured good and proper physiological conditions for rabbits (Laboratory Animal Science Association - Good Practice Guidelines: Collection of Blood Samples, October 1998; Directive 86/609/ EEC from November 24, 1986 for Protection of Vertebrate Animals Used for Experimental and Other Sciences Purpose; Romanian Law nr 205/2004; and Directive 2010/63/EU for Protection of Animals Used for Experimental and Other Scientific Purposes).

Thus, at four days after the second administration, after anesthesia, we collected blood samples for hematological analysis, into anticoagulant vacutainers (containing $\mathrm{K}_{3}$ EDTA) and homogenized them with gentle inversion (Waynforth et al., 1998). Hematological tests represented by a complete blood count, were performed at an authorized Clinical Private Laboratory, using Flow Cytometry method, with Impedance Analysis System.

The results were statistically processed and the final data are presented in tables, as averages $(\mathrm{X})$, standard deviations (SD), and we also calculated $\mathrm{T}$ test for $\mathrm{p}<0.05$.

\section{RESULTS AND DISCUSSIONS}

The aim of our research experiment was to evaluate the hematological homeostasis after iron overdoses for a short period of time in rabbits. Thus, in table 1 we presented the results (as average and standard deviation) for erythrocytes, leukocytes and platelets (or thrombocytes). Red blood cells or erythrocytes are the most numerous cells in blood, being rich in hemoglobin so, also rich in iron - a very important characteristic for our study. White blood cells or leukocytes have important function in organism, being involved in defense action or organism, while platelets or thrombocytes are involved in aggregation of some factors resulting in blood coagulation and stop bleeding.

Erythrocytes concentration in our blood samples presented very similar values for both control and experimental animals, even if these cells are carrier or hemoglobin which has in its

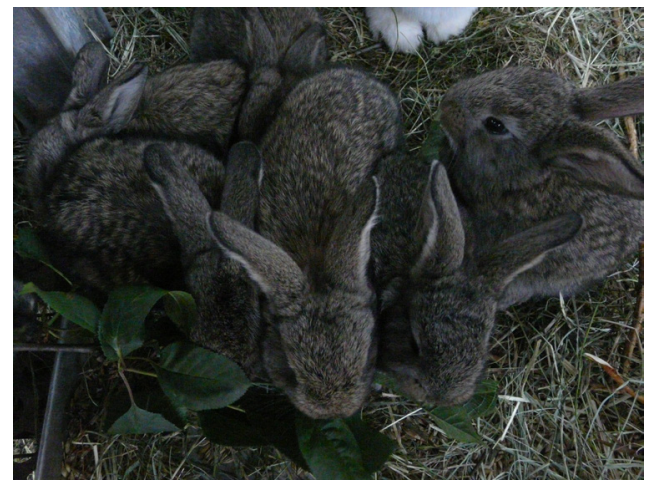

Figure 1. German Lop Eared rabbits from our experiment

Tab. 1. Data of erythrocytes (RBC), leukocytes (WBC), and platelets (Thrombocytes) for control and experimental rabbits

\begin{tabular}{cccc}
\hline \multirow{2}{*}{ Specification } & $\begin{array}{c}\text { Erythrocytes (RBC) } \\
\text { (millions/mm3) }\end{array}$ & $\begin{array}{c}\text { Leukocytes (WBC) } \\
\text { (thousand/mm3) }\end{array}$ & $\begin{array}{c}\text { Platelets (Thrombocytes) } \\
\text { (thousand/mm3) }\end{array}$ \\
\cline { 2 - 4 } & $\mathbf{X} \pm \mathbf{S D}$ & $\mathbf{X} \pm \mathbf{S D}$ & $\mathbf{X} \pm$ SD \\
\hline Control group & $5.415 \pm 0.134$ & $4.050 \pm 0.07$ & $513.50 \pm 19.09$ \\
\hline Experimental group & $5.110 \pm 0.181$ & $6.093 \pm 1.62$ & $741.66 \pm 64.05$ \\
\hline
\end{tabular}


structure the iron. This process can be due to a very short time for absorption of iron administration. Fiorelli (2007) reported that serum ferritin and transferrin saturation are often associated with elevated values of erythrocyte and hemoglobin. Other researchers evaluated the hepatic activity after iron poisoning. Thus, excess of iron in organism negatively affect the liver function, by altering the enzymatic system responsible for iron detoxification, due to free radical formation and depletion of low liver glutathione (Weinbaum et al., 2008).

Also, leukocytes number was slightly increased, but not significantly higher (T Test), for experimental rabbits compared to the control. We think that the increased number for leukocytes is not related to the iron excess intake, and can be correlated with the way of administration (intraperitoneal injection).

On the other hand the platelets number significantly increased for experimental rabbits compared to control animals, after iron excess intake. The iron excess should not be directly correlated to elevated number of platelets, because lots of researchers presented a direct correlation between anemia (iron deficiency) and high number of platelets (Kadikoylu, et al., 2006; Kurekci et al., 2000; Roshal, 2013; Witmer, 2013).

In table 2 are presented the analytical data for some of the hematological parameters, as average and standard deviation, for control and experimental rabbits, after iron excess, administrated intraperitoneal in a dose that provided 15g iron / body weight, as $\mathrm{Fe}^{2+}$.

As we expected, hemoglobin for experimental rabbits was significantly increased compared to control ones ( $\mathrm{T}$ test, $\mathrm{p}<0.05$ ). Hemoglobin concentration in blood samples was four times higher after iron administration in excess compared to the control group. Ferrous-gluconate hydro solution administrated to the rabbits made available a high quantity of iron in a very short time, which was absorbed into the liver and was carried out by blood cells in the organism. Thereby, erythrocytes increased the concentration of hemoglobin, which have captured the iron into its structure. This effect was expected to occur as long as the iron bioavailability in the gluconate formula was very good, even if we added to the diet plants knows as protective for hepatic detoxification process. Iron homeostasis was severely altered and the effect was easy to evaluate by the concentration of hemoglobin in whole blood samples. There are different approaches to iron intoxication and hematological perturbation in living organism. Coates (2014) presented a study about the relation between iron and physiology and pathophysiology of different diseases associated with hemoglobin.

The other evaluated blood parameters: the hematocrit, mean corpuscular volume, mean corpuscular hemoglobin, and mean corpuscular hemoglobin concentration did not present quantum modification possible due to a short time after iron intoxication. The protective diet for rabbits used in this experiment was based on fresh organic vegetables (roots and leaves), chosen especially because of the suspected benefic action.

Red cell distribution width presented in table 2 showed an increased percentage for experimental group compared to control group. Red cell distribution width is a parameter that evaluates the variation between the red blood cell size and red blood cell volume. Literature data demonstrated that in case of good physical activity associated with special diet, even in mineral homeostasis alteration, the red cell distribution

Tab. 2. Data of hemoglobin, hematocrit, mean corpuscular volume, mean corpuscular hemoglobin, mean corpuscular hemoglobin concentration, red cell distribution width of rabbits from control and experimental group

\begin{tabular}{|c|c|c|c|c|c|c|}
\hline \multirow[t]{2}{*}{ Specification } & $\begin{array}{c}\mathrm{Hbg} \\
\text { (g/dL) }\end{array}$ & $\begin{array}{l}\mathrm{HC} \\
(\%)\end{array}$ & $\begin{array}{l}\mathrm{MCV} \\
(\mathrm{fL})\end{array}$ & $\begin{array}{l}\mathrm{MCH} \\
(\mathrm{pg})\end{array}$ & $\begin{array}{l}\text { MCHC } \\
\text { (g/dL) }\end{array}$ & $\begin{array}{l}\text { RDW } \\
(\%)\end{array}$ \\
\hline & $\mathrm{X} \pm \mathrm{SD}$ & $\mathrm{X} \pm \mathrm{SD}$ & $\mathrm{X} \pm \mathrm{SD}$ & $\mathrm{X} \pm \mathrm{SD}$ & $\mathrm{X} \pm \mathrm{SD}$ & $\mathrm{X} \pm \mathrm{SD}$ \\
\hline Control group & $10.70 \pm 0.14$ & $36.15 \pm 0.21$ & $66.7 \pm 1.27$ & $19.85 \pm 0.21$ & $29.75 \pm 0.21$ & $12.7 \pm 0.00$ \\
\hline $\begin{array}{l}\text { Experimental group } \\
\text { Note: hemoglobin (Hbg), }\end{array}$ & $\frac{41.43 \pm 1.75^{*}}{\text { nematocrit }(\mathrm{HC}), \mathrm{m}}$ & $\frac{34.33 \pm 0.55}{\text { ean corpuscular }}$ & $\frac{70.9 \pm 1.28}{\text { olume (MCV), } \mathrm{m}}$ & $\begin{array}{r}21.03 \pm 0.59 \\
\text { an corpuscular } h\end{array}$ & $\frac{30.2 \pm 0.66}{\text { moglobin }(\mathrm{MCH})}$ & $\frac{17.16 \pm 0.50}{\text { mean corpuscula }}$ \\
\hline
\end{tabular}


width can be evaluated and can be maintained within normal range (Hajiboland et al., 2013).

Overall, the hematological blood tests did not presented significant differences between control group and experimental group of rabbits, which demonstrated that even in iron intoxication for a short time, diet can protect the organism.

\section{CONCLUSION}

In the present experimental research we demonstrated that fresh, organic plants can be effective for health protection and health enhancement of rabbit's organism, even with high doses of iron administrated for a short period of time.

Between the hematological evaluated parameters: erythrocytes (RBC), leukocytes (WBC), platelets (thrombocytes), hemoglobin (Hbg), hematocrit (HC), mean corpuscular volume (MCV), mean corpuscular hemoglobin (MCH), mean corpuscular hemoglobin concentration (MCHC), and red cell distribution width (RDW); we observed significantly increased values only for hemoglobin in experimental rabbits compared to control rabbits, after intraperitoneal administration of $15 \mathrm{~g}$ iron/Kg body weight, as ferrous-gluconate hydrated solution.

\section{REFERENCES}

1. Ahmad A, Husain A, Mujeeb M, Khan SA, Kundu, Najmi AK, Siddique NA, Damanhouri ZA, Anwar F (2013). A review on therapeutic potential of Nigella sativa: A miracle plant. Asian Pac J Trop Biomed, 3(5):337-352.

2. Beheshti F, Hosseini M, Vafaee F, Shafei MN, Soukhtanloo M (2016). Feeding of Nigella sativa during neonatal and juvenile growth improves learning and memory of rats, Journal of Traditional and Complementary Medicine, 6(2):146-152.

3. Coates TD (2014). Physiology and pathophysiology of iron in hemoglobin-associated diseases. Free Radic Biol and Med 72:23-40.

4. Dronca D (2007). Ameliorarea genetica a populatiilor de animale, Ed. Mirton, Timisoara.

5. Fiorelli G (2007). Serum ferritin and erythrocyte indices in iron overload. Blood Transfus. 5(4):187-188.

6. Hajiboland R, Barcelo J, Poschenrieder C, Tolra R (2013). Amelioration of iron toxicity: A mechanism for aluminuminduced growth stimulation in tea plans, J Inorg Biochem, 128:183-187.

7. Hurrell R, Egli I (2010) Iron bioavailability and dietary reference values, Am J Clin Nutr 91(suppl):1461S-7S.
8. Kadikoylu G, Yavasoglu I, Bolaman Z, Senturk T (2006). Platelet parameters in women with iron deficiency anemia, J Natl Med Assoc., 98(3):398-402.

9. Kundu J, Chun KS, Aruoma OI, Kundu JK (2014). Mechanistic perspectives on cancer chemoprevention / chemotherapeutic effects on thymoquinone, Mutat Res-Fund Mol M 768:22-34.

10. Kurekci A.E., Atay A.A., Sarici S.U., Zeybek C., Koseoglu V., Ozcan O. (2000) Effect of Iron Therapy on the Whole Blood Platelet Aggregation in Infants with Iron Deficiency Anemia, Thrombosis Research, 97(5):281-285.

11. Majdalawieh F. A., FayyadW.M.(2015) Immunomodulatory and anti-inflammatory action of Nigella sativa and thymoquinone: A comprehensive review, International Immunopharmacology, 28(1):295-304.

12. Periasamy V.S., Athinarayanan J., Alshatwi A.A. (2016) Anticancer activity of ultrasonic nanoemulsion formulation of Nigella sativa L. essential oil on human breast cancer cells, Untrasonic Sonochemistry, 31:449-455.

13. Roshal M. (2013) Chapter 133 - Measurement of Platelet Count, Mean Platelet Volume and Reticulated Platelets, in Transfusion Medicine and Hemostasis: Clinical and Laboratory Aspects (Shaz B.H., Hillyer C.D., Abrams C.S., Roshal M. - editors), Second edition, Elsevier Inc., 837841.

14. Sahebkar A., Beccuti G., Simental-Mendia L.E., Nobili V., Bo S. (2016) Nigella sativa (black seed) effects on plasma lipid concentrations in humans: A systematic riview and metaanalysis of randomized placebo-controlled trials, Pharmacological Research, 106:37-50.

15. Teucher B., Olivare M., Cori H. (2004) Enhancers of Iron Absorption Ascorbic Acid and other Organic Acids, Int. J. Vitam. Nutr. Res., 74(6):403-419.

16. Waynforth H.B., Brain P., Sharpe T., Stewart D.F., Applebee K.A., Darke G.D. (1998) Laboratory Animal Science Association - Good Practice Guidelines: Collection of Blood Samples (Rat, Mouse, Guinea Pig, Rabbit), Series 1/Issue 1 - October 1998, page 1-4, Tamworth, Staffordshire, UK.

17. Weinbaum S., Kozer E., Evans S., Bar-Haim A., Zandback Y., Lahat E., Petrov I., Alkan Y., Siman-Tov Y., Rechavi M., Goldstein L., Berkovitch M. (2008) Depletion of glutathione system enzymes of the liver and erythrocytes in a rat model of acute iron poisoning, Toxicol.Mech.Methods, Jan.18(8):623-6.

18. Witmer C.M. (2013) Hematologic Manifestations of Systemic Disease (Including Iron Deficiency, Anemia of Inflammation and DIC), Pediatric Hematology, 60(6):13371348.

19. Romanian Law nr 205/2004 (Art. 7, 8, 22), publ. in M.O. of Romania, Part I, Nr. 531/14.06.2004, Directive 86/609/ EEC from November 24, 1986 for Protection of Vertebrate Animals Used for Experimental and Other Sciences Purpose.

20. Directive 2010/63/EU of the European Parliament and of the Council of 22 September 2010 for Protection of Animals Used for Experimental and Other Scientific Purposes. 